\title{
COMMENTARY
}

\section{Does weight loss reduce plasma fibrinogen?}

Much interest is being shown in fibrinogen as a possible cardiovascular risk factor. ${ }^{1}$ The concept that fibrinogen is causally related to cardiovascular events is supported by several lines of evidence. Perhaps the strongest indication stems from seven prospective epidemiological trials ${ }^{2-8}$ all of which showed that fibrinogen predicts major cardiovascular events such as stroke and myocardial infarction. Clinical trials on survivors of a first myocardial infarction ${ }^{9}$ or stroke $^{10}$ also showed that fibrinogen was a risk factor for further cardiovascular disasters. Several plausible pathological mechanisms could explain this association ${ }^{1}$ : fibrinogen is an important clotting factor and it determines the flow properties of blood, represents a co-factor for platelet aggregation, and may cause atherosclerosis by direct effects on the arterial wall.

Acceptance that fibrinogen is a major cardiovascular risk factor will lead to attempts to lower its plasma concentration. Methods to achieve this are still in their infancy. Though dietary influences seem to be small, ${ }^{1}$ there is a striking association between body weight and fibrinogen. I will review the data suggesting that weight loss might be one practical way of influencing fibrinogen concentrations.

\section{Cross sectional data}

The baseline data of several epidemiological studies show a relation between fibrinogen and variables that reflect body weight. In the Scottish Heart Health Study ${ }^{11}$ the body mass index (BMI) and fibrinogen were significantly correlated. The PROCAM data confirmed this association and the fact that it was stronger in men than in women $^{12}$; the Broca index, (a formula to estimate ideal

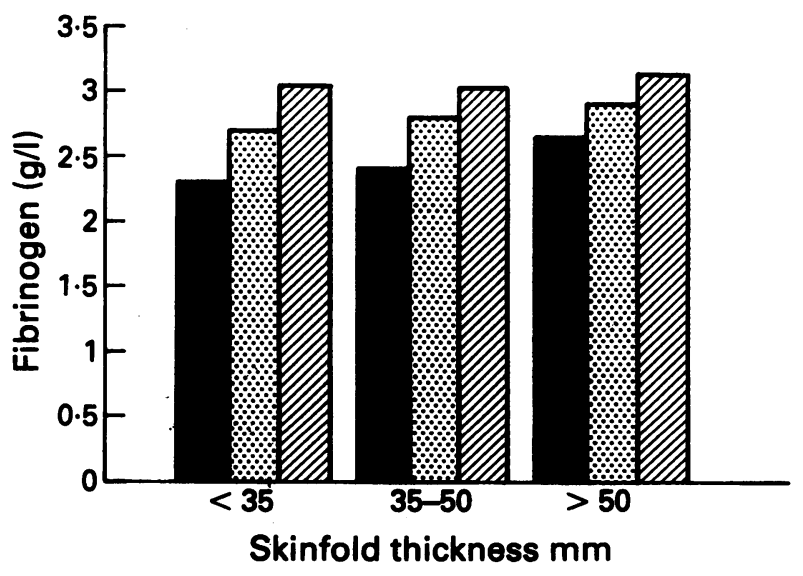

$18-34$ yr 35-49 yr 50-64 yr

Figure 1 Cross sectional data from the Northwick Park Heart Study. There is an increase in fibrinogen with skinfold thickness which is most pronounced in the younger age groups.
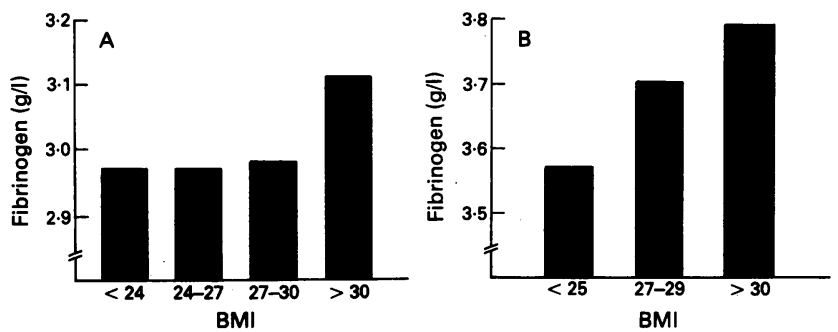

Figure 2 Cross sectional data on men from the (A) Arterioscelerosis Risk in Communities (ARIC) and (B) Göttinger Risiko Inzidenz und Prävalenz Studie (GRIPS) studies. Fibrinogen is raised particularly in the obese populations with BMI in excess of $30 \mathrm{~kg} / \mathrm{m}^{2}$.

weight: body length $(\mathrm{cm})-100=$ ideal weight in $\mathrm{kg}$ ) was significantly correlated with fibrinogen in this study. $(r=0.67, p<0.001$ in men; $r=0.306, p<0.001$ in women). There is a relation between absolute fibrinogen values and different BMI classes. ${ }^{712}$ Similarly, data from the Northwick Park Heart Study ${ }^{14}$ show a close relation between skinfold thickness and fibrinogen (fig 1). As part of the MONICA project ${ }^{15}$ plasma viscosity (strongly determined by fibrinogen) was measured in a random sample of the population. It was significantly increased in obese women but not in obese men. Similar data were reported in both the GRIPS ${ }^{6}$ and the ARIC $^{13}$ studies (fig 2).

Sample sizes are invariably smaller in clinical studies and therefore such studies may be more difficult to interpret. Our own laboratory compared a group ( 4 men and 10 women) obese individuals (Broca index exceeding $30 \%$ ) with no further risk factors with matched controls. ${ }^{16}$ Plasma viscosity was used to estimate fibrinogen concentrations. The results showed a considerable increase in fibrinogen in the obese individuals. This finding was later repeatedly confirmed by Craven $e t a l^{17}$ among others.

\section{Longitudinal data}

The cross sectional studies described above are strong evidence that fibrinogen is increased in overweight men an women. But they do establish a cause and effect relation: both factors could have a common denominator, such as a certain genetic trait. If this were true, the association would be non-causal and weight loss would not affect fibrinogen concentration. Longitudinal studies of weight reduction are needed to clarify the relation.

The largest longitudinal analysis is the Northwick Park Heart Study. ${ }^{18}$ Six years after entry, 1725 men in the original sample of 2114 , were re-examined. Complete data were available for 1465 sets. The change in fibrinogen (baseline versus 6 years' follow up) was examined in relation to changes in smoking habits, alcohol consumption, and changes in BMI. A pooled estimate showed a change of $0.17 \%$ in fibrinogen per unit change in BMI. The Northwick Park groups believe that part of the bene- 
fit of stopping smoking (a reduction in fibrinogen) is offset by the gain in body weight (an increase in fibrinogen) that often follows giving up smoking.

In morbidly obese patients a very low calorie intake for 15 days did not have any effect on fibrinogen concentration. ${ }^{19}$ Matrai and I studied long-term weight reduction in grossly obese individuals (BMI $31-39 \mathrm{~kg} / \mathrm{m}^{2}$ ). We found that plasma viscosity decreased in parallel (from a mean (SD) $1.31(0.08)$ to $1.25(0.06)(\mathrm{mPa} . \mathrm{s})$ with the body weight. ${ }^{20} \mathrm{~A}$ similar Belgian study in 20 obese patients confirmed that obesity was associated with hyperviscosity and found a decrease in fibrinogen of 0.27 $\mathrm{g} / 1$ over 6 months when the BMI fell from $32 \cdot 8$ (3.1) to $27.5) \mathrm{kg} / \mathrm{m}^{2} .^{21}$ An Italian group put 40 obese patients on a diet of $1000-1400 \mathrm{kcal} /$ day for one year. ${ }^{22}$ The fall in BMI from $36(6)$ to 29 (4) $\mathrm{kg} / \mathrm{m}^{2}$ was paralleled by a fall in fibrinogen concentration from 3.0 to $2.8 \mathrm{~g} / \mathrm{l}$. The same group studied obese children aged $7-14$ years on a $1000-1400 \mathrm{kcal}$ diet. ${ }^{23}$ Over 2 months the degree of overweight fell from $50.4(14.9)$ to $34.4(13.8) \%$ and plasma fibrinogen fell from 4.6 to $4 \cdot 2 \mathrm{~g} / \mathrm{l}$.

Last year an intriguing finding was reported from the United Kingdom ${ }^{24}$ : an inverse correlation was found between the fibrinogen concentration of adult men and their weight at 1 year and at birth. If, for instance, the weight at 1 year was less than 18 pounds, the ageadjusted fibrinogen in adult life was $3.2 \mathrm{~g} / \mathrm{l}$, whereas it was only $2.9 \mathrm{~g} / 1$ if the weight at one year was more than 26 pounds. Barker et al speculate that fibrinogen concentrations might be partly "programmed" in this early stage of life. ${ }^{24}$

When 13 healthy, non-overweight volunteers were put on two different diets, ${ }^{25}$ (containing $39 \%$ and $31 \%$ of total energy as fat) within two weeks there was a striking reduction in fibrinogen on the low fat diet (from 6.3 to $5 \cdot 8 \mu \mathrm{mol} / 1)$. No change was seen during the control diet. Total calories, fatty acid composition, and fibre content were identical in the two regimens. Fibrinogen concentration in 22 obese children aged 7-17 years fell considerably after only one month on a $1000 \mathrm{kcal} /$ day diet. ${ }^{26}$ Body weight (mean (SD)) dropped from 96.7 (16.2) to $84.8(14.9) \mathrm{kg}$ and fibrinogen fell from $4.2(1.4)$ to 3.0 $(0.9) \mathrm{g} / \mathrm{l}$. The duration of the diet is not specified. When a very low calorie diet $(524 \mathrm{kcal} /$ day) was given to 23 obese women for 3 months followed by a maintenance diet of $900-100 \mathrm{kcal} /$ day for a further 3 months. ${ }^{27}$ BMI decreased from $38.5(1.6)$ to $33.7(1.4)$ and fibrinogen fell from 2.8 to $2.6 \mathrm{~g} / 1$. The concentration of plasma fibrinogen did not change significantly during the first part of this regimen, it fell only in the second, less restricted phase. Finally when a large $(n=83)$ group of "healthy"

Longitudinal trials on the effects of weight reduction on fibrinogen

\begin{tabular}{|c|c|c|c|c|}
\hline First author & $\begin{array}{l}\text { Population } \\
\text { studied }\end{array}$ & Diet & $\begin{array}{l}\text { Change in } \\
\text { BMI }\end{array}$ & $\begin{array}{l}\text { Change in } \\
\text { fibrinogen } \\
(\mathrm{g} / \mathrm{l})\end{array}$ \\
\hline Meade & 1465 Adults & Variable & Variable & $\begin{array}{l}0 \cdot 17 \% / \text { unit } \\
\text { BMI }\end{array}$ \\
\hline Ernst & 7 & $\begin{array}{l}300 \mathrm{kcal} / \text { day for } \\
15 \text { days }\end{array}$ & $-7 \mathbf{k g}^{\star}$ & None \\
\hline Rillaerts & $\begin{array}{l}20 \text { Obese } \\
\text { adults }\end{array}$ & $\begin{array}{l}1000 \mathrm{kcal} / \mathrm{day} \text { for } \\
6 \text { months }\end{array}$ & $-5 \cdot 5$ & $-0 \cdot 27$ \\
\hline Craveri & $\begin{array}{l}40 \text { Obese } \\
\text { adults }\end{array}$ & $\begin{array}{l}1000-1400 \mathrm{kcal} / \text { day } \\
\text { for } 1 \text { year }\end{array}$ & -7 & $-0 \cdot 20$ \\
\hline Craveri & $\begin{array}{l}\text { Obese } \\
\text { children }\end{array}$ & $\begin{array}{l}1000-1400 \mathrm{kcal} / \text { day } \\
\text { for } 2 \text { months }\end{array}$ & $-16 \% \star$ & -0.40 \\
\hline Marckmann & $\begin{array}{l}13 \\
\text { Volunteers }\end{array}$ & $\begin{array}{l}31 \% \text { of total } \\
\text { energy fat }\end{array}$ & None & $\begin{array}{l}-0.5 \\
\mu \mathrm{mol} / 1\end{array}$ \\
\hline Fanari & $\begin{array}{l}22 \text { Obese } \\
\text { children and }\end{array}$ & $\begin{array}{l}1000 \mathrm{kcal} / \mathrm{day} \\
\text { for } 1 \mathrm{month}\end{array}$ & $-8 \mathbf{k g}{ }^{\star}$ & $-1 \cdot 2$ \\
\hline Poggi & $\begin{array}{l}23 \text { Obese } \\
\text { women }\end{array}$ & $\begin{array}{l}524 \mathrm{kcal} / \mathrm{day} \\
\text { for } 3 \text { months }\end{array}$ & -4.8 & $-0 \cdot 2$ \\
\hline
\end{tabular}

${ }^{\star}$ No BMI data available. obese individuals took an ill defined diet containing $10 \mathrm{~g}$ carbohydrates per day for 3 months, ${ }^{28}$ their mean (SD) fell from $83.3(21.4) \mathrm{kg}$ to $75.5(18.3) \mathrm{kg}$ and the fibrinogen concentration fell from $3 \cdot 2(0.9)$ to $2 \cdot 9(0 \cdot 8) \mathrm{g} /$.

\section{Conclusions}

Though the results of all studies (table 1) are not universally consistent most implied that fibrinogen was lowered when body weight became normal in obese individuals. The extent of the fibrinogen effect is not uniform. There is no clear correlation between the decrease in fibrinogen concentrations and the duration of the diet (short programmes, however, seem to have no effect) or the calorie intake. Severe, but short term reductions in calorie intake do not induce significant changes in fibrinogen.

Extrapolation from the Northwick Heart Health Study, ${ }^{2}$ in which the strength of the association of fibrinogen and coronary heart disease is typical of that in similar studies, suggests that a reduction of fibrinogen of $0.1 \mathrm{~g} / 1$ corresponds to a reduction in risk of $15 \% .^{29}$ Thus the fibrinogen reduction that can be achieved by weight loss may be of considerable clinical importance. The fibrinogen-lowering effect of weight loss is likely to work in concert with the better known effects of weight normalisation (such as, reduction of hypertension, glucose tolerance, and hyperlipoproteinaemia) to reduce the risk of major cardiovascular events.

The present findings suggest that weight loss can reduce fibrinogen and may contribute to a lowering of the cardiovascular risk. But the apparent inconsistencies between studies need to be resolved by further trials.

Universitätsklinik für Physikalische

E ERNST

Medizin und Rehabilitation,

Allgemeines Krankenhaus,

Währinger Gürtel 18-20,

1090 Vienna, Austria.

1 Ernst E, Koenig W, Lowe GDO, Meade TW. Fibrinogen, a "new" cardiovascular risk factor. Oxford; Blackwell 1992.

2 Meade TW, Mellows W, Brozovic M, Miller GJ, et al. Haemostatic function and ischemic heart disease: principal results of the Northwick Park Heart Study. Lancet 1986;ii:533-7.

3 Stone MC, Thorp JM: Plasma fibrinogen-a major coronary risk factor. f $R$ Coll Gen Pract 1985;35:565-9.

4 Kannel WB, Wolf PA, Castelli WP, D'Agostino RB: Fibrinogen and risk of cardiovascular disease. $\mathcal{F}$ Am Med Ass 1987;258:1 183-6.

5 Balleisen L, Schulte H, Assmann G, Epping PH, Van De Loo J. Coagulation factors and the progress of coronary heart disease. Lancet 1987;1:461.

6 Cremer P, Nagel D, Böttcher B, Seidel D: Fibrinogen: ein koronarer Risikofaktor. Diagnose Labor 1992;42:28-35.

7 Wilhelmsen L, Svärdsudd K, Korsan-Bengsten K, Larsson B, et al. Fibrinogen as a risk factor for stroke and myocardial infarction. $N$ Engl f Med 1984;311:501-5.

8 Yarnell JW, Baker LA, Sweetnam PM, Bainton D, O'Brien JR, Whitehead PJ. Fibrinogen, viscosity, and white blood cell count are major risk factors for ischemic heart disease. Circulation 1991;83: 836-44.

9 Martin JF, Bath PMW, Burr MI. Influence of platelets size on outcome after myocardial infarction. Lancet 1992;338:1409-11.

10 Resch KI, Ernst E, Matrai A, Paulsen HF: Fibrinogen and viscosity, risk factors for stroke survivors. Ann Intern Med 1992;117:371-5.

11 Lee AJ, Smith WCS, Lowe GDO, Tunstall-Pedoe H. Plasma fibrinogen and coronary risk factors: The Scottish Heart Health Study. $\mathcal{f}$ Clin Epidemiol 1990;43:913-9.

12 Balleisen L, Bailey J, Epping $\mathrm{PH}$, Schulte $\mathrm{H}$, Van De Loo J. Epidemiological study on factor VII, factor VIII and fibrinogen in an Epidemiological study on factor VII, factor VIII and

13 Folsom A. Fibrinogen and cardiovascular risk in the atherosclerosis risk in communities (ARIC) study. In: Ernst E, Koenig W, Lowe GDO, communities (ARIC) study. In: Ernst E, Koenig W, Lowe GDO, Meade TW, eds. Fibrin

14 Meade TW. Epidemiology of atheroma and thrombosis. In: Bloom AL, Thomas DP, eds. Haemostasis and thrombosis. London: Churchill Livingstone; 1981

15 Ernst E, Koenig W, Matrai A, Keil U. Plasma viscosity and hemoglobin in the presence of cardiovascular risk factors. Clin Hemorheol 1988;8:507-15.

16 Ernst E, Weihmayr T, Schmid M, Baumann M, Matrai A. Cardiovascular risk factors and hemorheology. Physical fitness, stress and obesity. Atherosclerosis 1986;59:263-9.

17 Craveri A, Tornaghi G, Paganardi L. Hemorheological changes in obesity. Clin Hemorheol 1988;8:723-36.

18 Meade TW, Imeson J, Stirling Y. Effects of changes in smoking and other 
characteristics on clotting factors and the risk of ischaemic heart disease. Lancet 1987;ii:986-9.

19 Ernst E, Weihmayr T, Matrai A, Resch KL. Changes in blood rheology of grossly obese individuals during a very low calorie diet. $₹$ Obesity 1989;13(suppl 2):162-8.

20 Ernst E, Matrai A. Normalization of hemorheologic abnormalities during weight reduction in obese patients. Nutrition 1987;3:337-9.

21 Rillaerts E, Vansant G, Van Gall L, De Leeuw J. Effect of weight reduction on blood viscosity parameters in obese women. Clin Hemorheol 1989;9:983-7.

22 Craveri A, Tornaghi G, Paganardi L. Weight loss does not affect the hemorheological and fibrinolytic changes in obesity. Clin Hemorheol hemorheological and fibrinolytic changes in obesity. Clin Hemorheol children and the effect of weight loss. Clin Hemorheol 1992;12:573-8.

24 Barker DJP, Meade TW, Fall CHD, Lee A, Osmond C, Phillips K Stirling Y. Relation of fetal and infant growth to plasma fibrinogen and factor VII concentration in adult life. $B r M e d ~ \%$ 1992;304:148-52.

25 Marckmann P, Sandström B, Jespersen J. Fasting blood coagulation and fibrinolysis of young adults unchanged by reduction in dietary fat content. Arterioscler Thromb 1992;12:201-5.

26 Fanari $P$, Somazzi R, Nasrawi F. Fibrinogen and blood rheology in obese children before and after slimming. In: Ernst E, Koeing W, Lowe GDO, Meade TW, eds. Fibrinogen as a "new" cardiovascular risk factor. Oxford: Blackwell, 1992;440-4.

27 Poggi M, Legnani C, Biagi $R$. Slimming after very low calorie diet in obese women. In: Ernst E, Koeing W, Lowe GDO, Meade TW, eds. Fibrinogen as a "new" cardiovascular risk factor. Oxford: Blackwell, Fibrinogen

28 Grohmann G, Pleissner R, Wessel G. Hämorheologische Untersuchungen bei Adipösen vor und nach Gewichtsreduktion. Perfusion (in press).

29 Wosornu D, Allardyce W, Ballantyne D, Tansey P. Influence of power and aerobic training on haemostatic factors after coronary surgery. $B$ Heart $\mathcal{F}$ 1992;68:181-6. 